\title{
Enhanced Corrosion of 7075 Alloy by the Presence of Bacillus megaterium
}

\author{
Nelson D. Vejar, ${ }^{1,2, *}$, Juan Sacre ${ }^{3}$, Bernardo Collao $^{3}$, José Perez-Donoso $^{3}$, Maritza A. Páez ${ }^{5}$, \\ Fabiola Pineda ${ }^{2}$,Benjamin Worker ${ }^{1,4}$ and Mamie Sancy, ${ }^{2, *}$ \\ ${ }^{1}$ Academia Politécnica Aeronáutica, Fuerza Aérea de Chile, Av. José Miguel Carrera 11087, El \\ Bosque, Santiago, Chile. \\ ${ }^{2}$ Escuela de Construcción Civil, Facultad de Ingeniería, Pontificia Universidad Católica de Chile. Av. \\ Vicuña Mackenna 4860, Santiago, Chile. \\ ${ }^{3}$ Centro de Bioinformática y Biología Integrativa (CBIB), Universidad Andres Bello, República 239, \\ Santiago, Chile \\ ${ }^{4}$ Department of Chemistry, United States Air Force Academy, 2355 Fairchild Drive, Suite 2N225, \\ USA \\ ${ }^{5}$ Departamento de Química de los Materiales, Facultad de Química y Biología, Universidad de \\ Santiago de Chile. Avenida Libertador Bernardo O’Higgins 3363, Santiago, Chile. \\ *E-mail: nevejar@uc.cl, mamiesancy@uc.cl
}

doi: $10.20964 / 2016.11 .33$

Received: 8 June 2016 / Accepted: 3 August 2016 / Published: 10 October 2016

\begin{abstract}
A Bacillus megaterium strain with corrosive properties was isolated from a bacterial community collected from the drain valve of a C130 aircraft principal fuel tank. This strain and the consortium present in the valve were studied microbiologically and electrochemically to evaluate the risk of corrosion. Aluminum alloy 7075 was used as a substrate and the corrosion behavior was studied in sterile minimal salt medium (MSM) as a function of immersion time. The isolation and characterization of the consortium by DNA sequencing showed that the bacterium with corrosive properties is closely related to B. megaterium. Electrochemical results revealed that the corrosion rate was not influenced in sterile and inoculated media with the consortium. However, a corrosive behavior was determined in presence of the isolated B. megaterium strain after 14 days immersion time. The effect might be related to interfacial local $\mathrm{pH}$ changes by oxygen reduction to $\mathrm{OH}^{-}$ions. Further, SEM examinations and EDX analysis of metallic samples exposure in inoculated media showed localized attacks.
\end{abstract}

Keywords: microbiologically influenced corrosion, biocorrosion, aluminum alloy, 7075, Bacillus megaterium

\section{$\underline{\text { FULL TEXT }}$}


(C) 2016 The Authors. Published by ESG (www.electrochemsci.org). This article is an open access article distributed under the terms and conditions of the Creative Commons Attribution license (http://creativecommons.org/licenses/by/4.0/). 